\title{
Is autologous cord blood transfusion effective and safe in preterm infants?
}

\author{
Beril Altaş Yavuz¹, Emel Okulu², Saadet Arsan², İlke Mungan Akın³, Begüm Atasay², \\ Ömer Erdeve 2 \\ ${ }^{1}$ Department of Pediatrics, Farabi Hospital, Konya, ${ }^{2}$ Division of Neonatology, Department of Pediatrics, Ankara University \\ School of Medicine, Ankara, ${ }^{3}$ Department of Neonatology, Medeniyet University, Göztepe Training and Research Hospital, \\ Istanbul, Turkey. E-mail: emelokulu@gmail.com \\ Received: 28th December 2016, Revised: 14th February 2017, Accepted 20th February 2017
}

Nearly half of all very low birth weight (VLBW) premature infants receive their first transfusion during the first two weeks of life, and $80 \%$ receive at least one blood transfusion by the end of their hospitalization ${ }^{1}$. These infants are exposed to risks inherent to allogeneic transfusions, such as transmission of infectious agents and immune suppression ${ }^{2-4}$.

Umbilical cord blood (UCB) has been suggested as a source for autologous transfusions ${ }^{1,5,6}$. Placental vessels contain a quarter to a third of the newborn blood volume, and the fetal blood left in the placental vessels may serve as a source of autologous blood ${ }^{7,8}$. Although studies have shown that the collection and the storage of UCB are feasible for transfusion in newborn infants, the use of UCB for transfusion in preterm infants is reported in few studies $5,8-12$. We previously tested the safety and feasibility of the collection and storage method of the autologous blood ${ }^{13}$. We herein report the results of our clinical study to investigate the efficacy and safety of autologous cord blood transfusions in VLBW premature infants. UCB of infants born before the 32 weeks' gestation was collected by the same pediatrician who was trained specially for this procedure and who could be ready at all preterm deliveries between March 2009 and September 2010 at the Division of Neonatology, Department of Pediatrics, Department of Gynecology and Obstetrics, and Serpil Akdağ Blood Bank of Ankara University School of Medicine. The patients were randomized to receive the autologous or the allogeneic product labeled for each patient at birth in the blood bank. UCB was obtained from the placentas of 50 premature infants, overall, 39 infants were analyzed. Sixteen of 31 transfused patients had been randomized to the autologous group, and the remaining 15 patients had been randomized to the allogeneic group (Fig. 1). The collected UCB volume was not well correlated with the birth weight $\left(r^{2}=0.47\right)$, while there was an inverse correlation between the relative volume per kilogram birth weight and the birth weight $\left(r^{2}=-0.26\right)$ which was similar as reported by Anderson et $\mathrm{al}^{14}$. Eight patients never received a transfusion during their hospital stay, and these babies had higher mean gestational age and a mean birth weight than the transfused groups $(p=0.009$ and $p=0.04)$. The volume of collected UCB could not cover all transfusion needs, but replaced nearly one third of all transfusions in this group. The hemoglobin levels at birth, $14^{\text {th }}, 28^{\text {th }}$, and the $35^{\text {th }}$ days, postconceptional $36^{\text {th }}$ and the $40^{\text {th }}$ weeks' gestation, and 6-months age, the total number and volume of transfusions and phlebotomies were similar (Table I). There was not any bacterial growth in our cord blood samples, and none of the transfusions were complicated.

Despite the use of restrictive transfusion guidelines, most premature infants are still frequently transfused ${ }^{15-17}$. Recently, the use of UCB for transfusion purposes has gained clinical interest. Several studies have shown that it is technically feasible to process and store autologous placental blood like allogeneic blood $5,6,8,11,18-20$. Cord blood transfusion has some advantages such as to have immediate availability and to include high levels of hematopoietic progenitor cells. It has been demonstrated that cord blood stem and progenitor cells, may reconstitute marrow hematopoesis. UCB, enriched with self hematopoietic growth factors and progenitor cells, may be beneficial to premature infants who lack marrow reserves 21,22 . 
Table I. The Placental Weight, the Volume of UCB and Phlebotomies, and Hb Levels of Infants.

\begin{tabular}{|c|c|c|c|c|c|}
\hline & $\begin{array}{l}\text { Autologous } \\
\text { group } \\
(\mathrm{n}=16)\end{array}$ & $\begin{array}{l}\text { Allogeneic } \\
\text { group } \\
(\mathrm{n}=15)\end{array}$ & $\mathrm{p}$ & $\begin{array}{l}\text { Not-transfused } \\
\text { group } \\
(\mathrm{n}=8)\end{array}$ & $\mathrm{p}$ \\
\hline Placental weight $(\mathrm{g})^{*}$ (range) & $\begin{array}{l}399.7 \pm 174.6 \\
(280-620)\end{array}$ & $\begin{array}{l}344 \pm 11.2 \\
(200-560)\end{array}$ & .35 & $\begin{array}{l}408.1 \pm 138 \\
(280-610)\end{array}$ & .31 \\
\hline $\begin{array}{l}\text { Collected UCB volume }(\mathrm{ml})^{*} \\
\text { (range) }\end{array}$ & $\begin{array}{l}35.2 \pm 9.7 \\
(22-56)\end{array}$ & $\begin{array}{l}31 \pm 5.9 \\
(20-46)\end{array}$ & .28 & $\begin{array}{l}39.2 \pm 7.9 \\
(28-50)\end{array}$ & .07 \\
\hline $\begin{array}{l}\text { Umbilical cord } \\
\mathrm{Hb}(\mathrm{g} / \mathrm{dl})^{*}\end{array}$ & $\begin{array}{l}17 \pm 1.7 \\
(15-19.8)\end{array}$ & $\begin{array}{l}17.3 \pm 1.7 \\
(15-22)\end{array}$ & .62 & $\begin{array}{l}18.5 \pm 1.5 \\
(16-21)\end{array}$ & .12 \\
\hline & $38.2 \pm 22.4$ & $39.4 \pm 19$ & .82 & $12.7 \pm 2.2$ & .04 \\
\hline $\mathrm{Hb}$ at $14^{\text {th }}$ day $(\mathrm{g} / \mathrm{dl})^{*}$ & $12.8 \pm 0.9$ & $13.6 \pm 1.5$ & .13 & $13.4 \pm 1.6$ & .12 \\
\hline $\mathrm{Hb}$ at $28^{\text {th }}$ day $(\mathrm{g} / \mathrm{dl})^{*}$ & $11.8 \pm 1.3$ & $11.6 \pm 1.0$ & .63 & $11.9 \pm 1.3$ & .8 \\
\hline $\mathrm{Hb}$ at $35^{\text {th }}$ day $(\mathrm{g} / \mathrm{dl})^{*}$ & $10.7 \pm 1.7$ & $11.2 \pm 1.9$ & .47 & $11.2 \pm 1.1$ & .7 \\
\hline $\mathrm{Hb}$ at $36^{\text {th }} \mathrm{GW}(\mathrm{g} / \mathrm{dl})^{*}$ & $10.2 \pm 1.1$ & $10.1 \pm 1.2$ & .7 & $10.9 \pm 1.6$ & .3 \\
\hline $\mathrm{Hb}$ at $40^{\text {th }} \mathrm{GW}(\mathrm{g} / \mathrm{dl})^{*}$ & $\begin{array}{l}9.7 \pm 1.3 \\
\mathrm{n}=13\end{array}$ & $\begin{array}{l}10 \pm 1.5 \\
\mathrm{n}=14\end{array}$ & .6 & $\begin{array}{l}10.4 \pm 0.9 \\
\mathrm{n}=7\end{array}$ & .5 \\
\hline $\mathrm{Hb}$ at 6 months age $(\mathrm{g} / \mathrm{dL})$ & $12.2 \pm 0.8$ & $11.9 \pm 0.8$ & .55 & $11.8 \pm 1.1$ & .41 \\
\hline
\end{tabular}

UCB: umbilical cord blood, Hb: hemoglobin, GW: gestation week

* Data are reported as mean $\pm \mathrm{SD}$

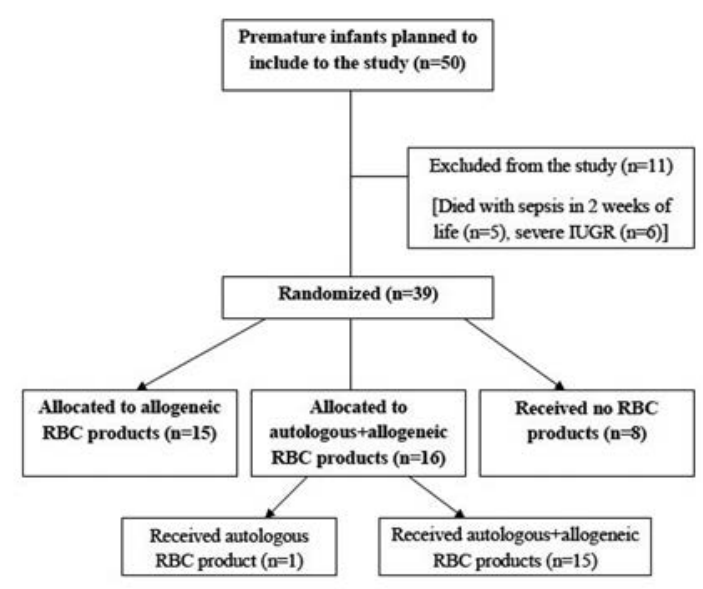

IUGR: Intrauterin growth restriction, RBC: Red blood cell

Fig. 1. Trial profile

Phlebotomy loss is a significant contributor to anemia in premature infants. A wide variation in phlebotomy loss of premature infants have been reported $(7-51 \mathrm{ml} / \mathrm{kg})$. In our patient population, the role of ongoing phlebotomy losses was considered as an additional cause for transfusion needs. Cord red blood cell (RBC) source was not sufficient to meet all transfusion needs in the group assigned to have autologous transfusions but at least could decrease allogeneic blood exposure by one third in these patients.
In conclusion, our study showed that autologous cord bloods have the similar efficacy and safety with the allogeneic bloods in VLBW premature infants. Although cord RBC source was not sufficient to meet all transfusion needs, but at least could decrease allogeneic blood exposure in these patients and it might be benefical as a supplemental source for transfusions in VLBW premature infants. Careful monitorization of phlebotomy losses for laboratory testing, and implementing more restrictive transfusion guidelines may increase the efficacy of cord blood. In this group of infants, placentofetal transfusion during delivery by holding the newborn below the level of the uterus and delaying cord clamping or 'milking' of the cord might present alternative preventive measures for anemia of prematurity.

\section{REFERENCES}

1. Bifano E, Curran T. Minimizing donor blood exposure in the neonatal intensive care unit. Current trends and future prospects. Clin Perinatol 1995; 22: 657-669.

2. Sacher RA, Strauss RG, Luban NL, et al. Blood component therapy during the neonatal period: A national survey of red cell transfusion practice. Transfusion 1990; 30: 271-276.

3. Strauss RG. Data-driven blood banking practices for neonatal RBC transfusions. Transfusion 2000; 40: 1528-1540. 
4. Strauss RG. How I transfuse red blood cells and platelets to infants (invited commentary). Transfusion 2008; 48: 209-217.

5. Eichler H, Schaible T, Richter E, et al. Cord blood as a source of autologous RBCs for transfusion to preterm infants. Transfusion 2000; 40: 1111-1117.

6. Surbek DV, Glanzmann R, Senn HP, Hoesli I, Holzgreve W. Can cord blood be used for autologous transfusion in preterm neonates? Eur J Pediatr 2000; 159: 790-791.

7. Linderkamp O. Placental transfusion: Determinants and effects. Clin Perinatol 1982; 9: 559-592.

8. Ballin A, Arbel E, Kenet G, et al. Autologous umbilical cord blood transfusion. Arch Dis Child Fetal Neonatal Ed 1995; 73: F181-F183.

9. Horn S, Mazor D, Zmora E, Meyerstein N. Storage induced changes in human newborn erythrocytes. Transfusion 1987; 27: 411-414.

10. Bifano EM, Dracker RA, Lorah K, Palit A. collection and 28-day storage of human placental blood. Pediatr Res 1994; 36: 90-94.

11. Brune T, Garritsen H, Witteler R, et al. Autologous placental blood transfusion for the therapy of anaemic neonates. Biol Neonate 2002; 81: 236-243.

12. Khodabux CM, von Lindern JS, van Hilten JA, Scherjon S, Walther FJ, Brand A. A clinical study on the feasibility of autologous cord blood transfusion for anemia of prematurity. Transfusion 2008; 48: 1634-1643.

13. Sahyoun-Tokan R, Arsan S, Erdeve O, et al. Comparison of stored umbilical cord blood with donated adult blood: study for transfusion feasibility. Turk J Haematol 2012; 29: 233-241.

14. Anderson S, Fangman J, Wager G, Uden D. Retrieval of placental blood from the umbilical vein to determine volume, sterility, and presence of clot formation. Am J Dis Child 1992; 146: 36-39.
15. Mimica AF, dos Sanos AM, da Cunha DH, et al. A very strict guideline reduces the number of erythrocyte transfusion in preterm infants. Vox Sang 2008; 95: 106-111.

16. Bell EF, Strauss RG, Widness JA, et al. Randomized trial of liberal versus restrictive guidelines for red blood cell transfusion in preterm infants. Pediatrics 2005; 115:1685-1691.

17. Kirpalani H, Whyte RK, Anderson C, et al. The Premature Infants in Need of Transfusion (PINT) study: a randomized, controlled trial of a restrictive (low) versus liberal (high) transfusion threshold for extremely low birth weight infants. J Pediatr 2006; 149:301-317.

18. Brune T, Garritsen H, Hentschel R, Louwen F, Harms E, Jorch G. Efficacy, recovery, and safety of RBCs from autologous placental blood: clinical experience in 52 newborns. Transfusion 2003; 43: 1210-1215.

19. Jansen M, Brand A, von Lindern JS, Scherjon S, Walther FJ. Potential use of autologous umbilical cord blood red blood cells for early transfusion needs of premature infants. Transfusion 2006; 46: 1049-1056.

20. Hassall O, Maitland K, Fegan G, et al. The quality of stored umbilical cord and adult-donated whole blood in Mombasa, Kenya. Transfusion 2010; 50: 611-616.

21. Laver J, Duncan E, Abboud M, et al. High levels of granulocyte and granulocyte-macrophage-colonystimulating factors in cord blood of normal full-term neonates. J Pediatr 1990; 116: 627-632.

22. Broxmeyer HE, Kurtzberg J, GGluckman E, et al. Umbilical cord blood hematopoietic stem and repopulating cells in human clinical transplantation. Blood Cells 1991; 17: 313-329. 